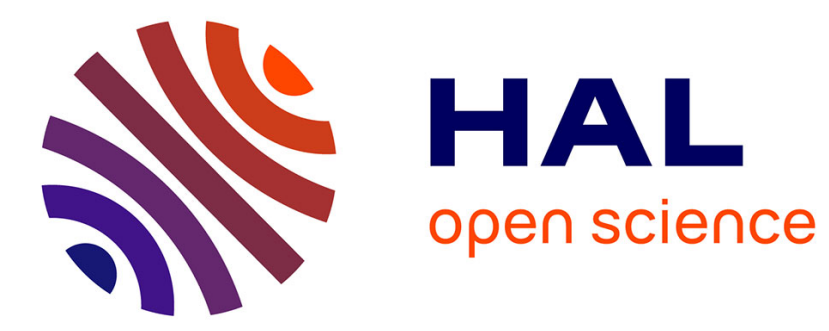

\title{
Clinical characteristics of viral intestinal infection in preterm and term neonates
}

S. Bagci, A. M. Eis-Hübinger, A. F. Yassin, A. Simon, P. Bartmann, A. R. Franz, A. Mueller

\section{> To cite this version:}

S. Bagci, A. M. Eis-Hübinger, A. F. Yassin, A. Simon, P. Bartmann, et al.. Clinical characteristics of viral intestinal infection in preterm and term neonates. European Journal of Clinical Microbiology and Infectious Diseases, 2010, 29 (9), pp.1079-1084. 10.1007/s10096-010-0965-4 . hal-00601640

\section{HAL Id: hal-00601640 \\ https://hal.science/hal-00601640}

Submitted on 20 Jun 2011

HAL is a multi-disciplinary open access archive for the deposit and dissemination of scientific research documents, whether they are published or not. The documents may come from teaching and research institutions in France or abroad, or from public or private research centers.
L'archive ouverte pluridisciplinaire HAL, est destinée au dépôt et à la diffusion de documents scientifiques de niveau recherche, publiés ou non, émanant des établissements d'enseignement et de recherche français ou étrangers, des laboratoires publics ou privés. 
Diseases

Editorial Manager(tm) for European Journal of Clinical Microbiology \& Infectious

Manuscript Draft

Manuscript Number: EJCMID-D-10-00107R1

Title: CLINICAL CHARACTERISTICS OF VIRAL INTESTINAL INFECTION IN PRETERM AND TERM NEONATES

Article Type: Article

Keywords: keyword 1: Norovirus

keyword 2: Rotavirus

keyword 3: Astrovirus

keyword 4: Necrotizing enterocolitis

keyword 5: Neonates

Corresponding Author: Dr Soyhan Bagci, M.D.

Corresponding Author's Institution: Children's Hospital, University of Bonn

First Author: Soyhan Bagci, M.D.

Order of Authors: Soyhan Bagci, M.D.; Anna M Eis-Hübinger, VMD, PhD; Atteyet F Yassin, M.D.; Arne Simon, M.D.; Peter Bartmann, M.D.; Axel Franz, M.D.; Andreas Müller, M.D.

Abstract: Objectives: The clinical presentation of the viral enteric pathogens in newborn infants has not been adequately examined. The aim of this study was to evaluate the clinical characteristics of viral intestinal infections in newborn infants.

Methods: Clinical data of all term and preterm infants admitted to our tertiary neonatal intensive care unit from 1998 to 2007 with clinical signs of gastroenteritis (GE) or necrotizing enterocolitis (NEC) were retrospectively reviewed and compared between infants with different viral enteric pathogens in stool specimens.

Results: In thirty-four infants with signs of GE or NEC, enteropathogenic viruses were found in stool specimens. Rotavirus was detected in 12 cases, of which 2 infants had NEC. Compared with infants with rotavirus or norovirus, infants with astrovirus more frequently suffered from NEC $(\mathrm{p}<0.05)$. In addition, an acute systemic inflammatory response was significantly more common in patients with astrovirus infection (astrovirus vs. rotavirus and astrovirus vs. norovirus $\mathrm{p}<0.01$ and $\mathrm{p}<0.05$, respectively). Of 8 children infected with norovirus, one infant had a systemic acute inflammatory response and NEC.

Conclusions: This study demonstrates that in newborn infants, intestinal rotavirus, norovirus, and astrovirus infections may be associated with severe illness such as hemorrhagic enteritis resulting in bloody diarrhea or even NEC.

Response to Reviewers: Ms. Ref. No.: EJCMID-D-10-00107

Title: Clinical characteristics of viral intestinal infection in preterm and term neonates Authors: Soyhan Bagci, Anna M. Eis-Hübinger, Atteyet F. Yassin, Arne Simon, Peter Bartmann, Axel R. Franz, Andreas Mueller

Dear Sir, 
We revised our manuscript "Clinical characteristics of viral intestinal infection in preterm and term neonates" according to the reviewers' comments.

You may find our comments, additions and answers below (all changes made to the manuscript text are underlined).

Reviewers' Comment 1: In the Abstract, under the Objectives paragraph it is stated that "The clinical presentation of viral intestinal infections in preterm and term neonates has not been adequately evaluated". This statement is not an objective in itself. It is an observation that could be included as background or as part of the introduction. The aims of the study should be better defined.

Answer 1: According the reviewers' suggestions we revised the objectives in the abstract. Because of "200 words-limit in abstract" we revised the abstract, too (all changes made to the manuscript text are underlined).

Reviewers' Comment 2: In the Results section (p.2, line 19) it should be mentioned that enteropathogenic viruses were found in 34 infants out of 220 (15.45\%) infants with gastroenteritis (GE) and NEC (nectotizing enterocolitis).

Answer 2: According the reviewers' suggestions we changed the sentence as recommended (Page 6, p.2).

Reviewers' Comment 3: Among 112 infants with gastroenteritis, enteric viruses were detected in 22 patients (19.64\%), and in 12 cases (11.11\%) out of 108 infants with NEC. That means that approximately only in one case out of every 10 infants suffering of NEC was an enteric virus detected. The majority of cases with RV infection (10/12) were mild and self-limiting GE, but 2 preterm infants had signs of NEC. In this study, no enteric viruses were detected among 186 infants with the diagnosis of GE or NEC. Despite these observations, the authors conclude (Abstract, p. 2, line 39) that this study demonstrates that in newborn infants, intestinal rotavirus, norovirus, and astrovirus infections may be associated with severe illness such as hemorrhagic enteritis resulting in bloody diarrhea or even NEC. The important question that needs to be answered is whether this association is significant or not, and this answer is not given.

Answer 3: This topic is extensively discussed in the discussion on pages 9 and 10 (p.3, about our patients with HAstV and p.4, about NV).

Reviewers' Comment 4: It is remarkable that the virus most frequently detected in cases of NEC is human astrovirus ( 9 infants), whereas in only 5 infants with GE was this virus found. This topic was already addressed by the authors of the present manuscript in a previously published paper (Bagci et al., 2008: Detection of astrovirus in premature infants with necrotizing enterocolitis. Pediatr Infect Dis J 27:347-50). In fact, 6 infants with NEC and astrovirus infection were already reported in that paper.

Answer 4: Our previous publication (Bagci et al., 2008: Detection of astrovirus in premature infants with necrotizing enterocolitis. Pediatr Infect Dis J 27:347-50) pointed at the association between HAstV and NEC for the first time. In this study, only patients with NEC were analyzed. In our present study, neonatal characteristics and clinical findings of newborns with enteric viral infection (NEC and GE) are summarized and a statistical analysis according to agents was performed. Therefore, we had to add these 6 patients from our previous study to the present study.

Reviewers' Comment 5: In several sentences it is said that viruses may 'colonize' the gut: "colonization or infection with HAstV" (Abstract, p. 3, line 29), "RV infection or colonization" (Discussion, p. 8, line 29; p. 10, lines 34 and 51). What do the authors mean with viral colonization? In regard to viruses, what is the difference between colonization and infection? 
Answer 5: The pathogenesis of NEC remains unclear. Several studies have reported that early abnormal bacterial colonization plays a key role in the development of NEC $(1,2)$. But it is still unclear, whether viral colonization of the gastrointestinal tract without cytolysis and cell destruction may play a role in the pathogenesis of NEC in newborn infants. Therefore, we preferred to use "infection or colonization", until we understand the role of enteric viruses in the pathophysiology of NEC.

Reviewers' Comment 6: It is stated that all patients who shared a room with an infected infant were immediately tested for enteric viruses. Were viruses found in asymptomatic infants? Were dual (mixed) viral infections detected? Apparently no adenovirus infections were found. These results should be clearly presented.

Answer 6: According the reviewers' suggestions the following sentences have been added to results (Results, p. 4): "No adenovirus was identified." and "Moreover, RV was detected in the second stool specimen of an infant with HAstV who was admitted to the group of HAstV."

Reviewers' Comment 7: In the Discussion, first paragraph, it is included the citation to reference 7, Rotbart et al. (1983), as a recent description of the association of viral agents with NEC. A 27-years-old paper cannot be considered as "recent".

Also, citations to reference 20 (Mumphrey et al., 2007) in the same paragraph (p. 8, line 7 and line 22) to document the association of viral agents with the pathogenesis of hemorrhagic enteritis or NEC is not appropriate.

Answer 7: We corrected these errors which resulted from an error of the reference manager.

We thank you for reviewing the manuscript.

Yours sincerely,

Soyhan Bagci,

Department of Neonatology, Children's Hospital, University of Bonn, Adenauerallee 119, D-53113 Bonn, Germany.

Tel.: ++49-228-287-33408

Fax: ++49-228-287-16291

E-mail: soyhan.bagci@ukb.uni-bonn.de

References:

1- Hoy C, Millar MR, MacKay P, Godwin PG, Langdale V and Levene MI. Quantitative changes in faecal microflora preceding necrotising enterocolitis in premature neonates. Arch Dis Child 1990;65:1057-9

2- de la Cochetiere MF, Piloquet H, des Robert C, Darmaun D, Galmiche JP and Roze JC. Early intestinal bacterial colonization and necrotizing enterocolitis in premature infants: the putative role of Clostridium. Pediatr Res 2004;56:366-70 


\section{University of Bonn}

Department of Neonatology, Children's Hospital, University of Bonn, Adenauerallee 119, D-53113 Bonn

Dr. S. Bagci, M.D.

Department of Neonatology,

Children's Hospital,

University of Bonn,

Adenauerallee 119

53113 Bonn, Germany

Phone: $\quad 0049-228-287-33408$

Fax: 0049-228-287-6291

Email: $\quad$ soyhan.bagci@ukb.uni-bonn.de

Bonn, 03/05/2010

Ms. Ref. No.: EJCMID-D-10-00107

Title: Clinical characteristics of viral intestinal infection in preterm and term neonates

Authors: Soyhan Bagci, Anna M. Eis-Hübinger, Atteyet F. Yassin, Arne Simon, Peter Bartmann, Axel R. Franz, Andreas Mueller

\section{Dear Sir,}

We revised our manuscript "Clinical characteristics of viral intestinal infection in preterm and term neonates" according to the reviewers' comments.

You may find our comments, additions and answers below (all changes made to the manuscript text are underlined).

Reviewers' Comment 1: In the Abstract, under the Objectives paragraph it is stated that "The clinical presentation of viral intestinal infections in preterm and term neonates has not been adequately evaluated". This statement is not an objective in itself. It is an observation that could be included as background or as part of the introduction. The aims of the study should be better defined.

Answer 1: According the reviewers' suggestions we revised the objectives in the abstract. Because of "200 words-limit in abstract" we revised the abstract, too (all changes made to the manuscript text are underlined).

Reviewers' Comment 2: In the Results section (p.2, line 19) it should be mentioned that enteropathogenic viruses were found in 34 infants out of 220 (15.45\%) infants with gastroenteritis (GE) and NEC (nectotizing enterocolitis).

Answer 2: According the reviewers' suggestions we changed the sentence as recommended (Page 6, p.2).

Reviewers' Comment 3: Among 112 infants with gastroenteritis, enteric viruses were detected in 22 patients (19.64\%), and in 12 cases (11.11\%) out of 108 infants with NEC. That means that approximately only in one case out of every 10 infants suffering of NEC was an enteric virus detected. The majority of cases with RV infection (10/12) 
were mild and self-limiting GE, but 2 preterm infants had signs of NEC. In this study, no enteric viruses were detected among 186 infants with the diagnosis of GE or NEC. Despite these observations, the authors conclude (Abstract, p. 2, line 39) that this study demonstrates that in newborn infants, intestinal rotavirus, norovirus, and astrovirus infections may be associated with severe illness such as hemorrhagic enteritis resulting in bloody diarrhea or even NEC. The important question that needs to be answered is whether this association is significant or not, and this answer is not given.

Answer 3: This topic is extensively discussed in the discussion on pages 9 and 10 (p.3, about our patients with HAstV and p.4, about NV).

Reviewers' Comment 4: It is remarkable that the virus most frequently detected in cases of NEC is human astrovirus ( 9 infants), whereas in only 5 infants with GE was this virus found. This topic was already addressed by the authors of the present manuscript in a previously published paper (Bagci et al., 2008: Detection of astrovirus in premature infants with necrotizing enterocolitis. Pediatr Infect Dis J 27:347-50). In fact, 6 infants with NEC and astrovirus infection were already reported in that paper.

Answer 4: Our previous publication (Bagci et al., 2008: Detection of astrovirus in premature infants with necrotizing enterocolitis. Pediatr Infect Dis $J$ 27:347-50) pointed at the association between HAstV and NEC for the first time. In this study, only patients with NEC were analyzed. In our present study, neonatal characteristics and clinical findings of newborns with enteric viral infection (NEC and GE) are summarized and a statistical analysis according to agents was performed. Therefore, we had to add these 6 patients from our previous study to the present study.

Reviewers' Comment 5: In several sentences it is said that viruses may 'colonize' the gut: "colonization or infection with HAstV" (Abstract, p. 3, line 29), "RV infection or colonization" (Discussion, p. 8, line 29; p. 10, lines 34 and 51). What do the authors mean with viral colonization? In regard to viruses, what is the difference between colonization and infection?

Answer 5: The pathogenesis of NEC remains unclear. Several studies have reported that early abnormal bacterial colonization plays a key role in the development of $\operatorname{NEC}(1,2)$. But it is still unclear, whether viral colonization of the gastrointestinal tract without cytolysis and cell destruction may play a role in the pathogenesis of NEC in newborn infants. Therefore, we preferred to use "infection or colonization", until we understand the role of enteric viruses in the pathophysiology of NEC.

Reviewers' Comment 6: It is stated that all patients who shared a room with an infected infant were immediately tested for enteric viruses. Were viruses found in asymptomatic infants? Were dual (mixed) viral infections detected? Apparently no adenovirus infections were found. These results should be clearly presented.

Answer 6: According the reviewers' suggestions the following sentences have been added to results (Results, p. 4): "No adenovirus was identified." and "Moreover, RV was detected 
in the second stool specimen of an infant with HAstV who was admitted to the group of HAstV."

Reviewers' Comment 7: In the Discussion, first paragraph, it is included the citation to reference 7, Rotbart et al. (1983), as a recent description of the association of viral agents with NEC. A 27-years-old paper cannot be considered as "recent".

Also, citations to reference 20 (Mumphrey et al., 2007) in the same paragraph (p. 8, line 7 and line 22) to document the association of viral agents with the pathogenesis of hemorrhagic enteritis or NEC is not appropriate.

Answer 7: We corrected these errors which resulted from an error of the reference manager.

We thank you for reviewing the manuscript.

Yours sincerely,

Soyhan Bagci,

Department of Neonatology, Children's Hospital, University of Bonn, Adenauerallee 119, D-53113 Bonn, Germany.

Tel.: ++49-228-287-33408

Fax: ++49-228-287-16291

E-mail: soyhan.bagci@ukb.uni-bonn.de

\section{References:}

1- Hoy C, Millar MR, MacKay P, Godwin PG, Langdale V and Levene MI. Quantitative changes in faecal microflora preceding necrotising enterocolitis in premature neonates. Arch Dis Child 1990;65:1057-9

2- de la Cochetiere MF, Piloquet H, des Robert C, Darmaun D, Galmiche JP and Roze JC. Early intestinal bacterial colonization and necrotizing enterocolitis in premature infants: the putative role of Clostridium. Pediatr Res 2004;56:366-70 


\section{CLINICAL CHARACTERISTICS OF VIRAL INTESTINAL INFECTION IN PRETERM AND TERM NEONATES}

Soyhan Bagci, $M D^{a^{*}}$, Anna M. Eis-Hübinger, VMD, $P h D^{b}$, Atteyet F. Yassin, $M D^{c}$, Arne Simon, $\mathrm{MD}^{\mathrm{d}}$, Peter Bartmann, MD, $\mathrm{PhD}^{\mathrm{a}}$, Axel R. Franz, $\mathrm{MD}^{\mathrm{a}}$, Andreas Mueller, $\mathrm{MD}^{\mathrm{a}}$ ${ }^{a}$ Department of Neonatology, Children's Hospital; ${ }^{b}$ Institute of Virology; ' Institute for Medical Microbiology, Immunology, and Parasitology; dDepartment of Pediatric Hematology and Oncology, Children's Hospital, University of Bonn

${ }^{*}$ Address for correspondence to Dr. Soyhan Bagci, Department of Neonatology, Children's Hospital, University of Bonn, Adenauerallee 119, D-53113 Bonn, Germany. Tel.: ++49-228-287-33408

Fax: ++49-228-287-16291

E-mail: soyhan.bagci@ukb.uni-bonn.de

Financial disclosure: No financial support

Conflict of interest: All authors no conflict

Keywords: Norovirus, rotavirus, astrovirus; necrotizing enterocolitis; neonates

Abbreviated title: Outcome of viral intestinal infection in newborn infants

Running title: Viral intestinal infection in neonates 


\begin{abstract}
Objectives: The clinical presentation of the viral enteric pathogens in newborn infants has not been adequately examined. The aim of this study was to evaluate the clinical characteristics of viral intestinal infections in newborn infants.
\end{abstract}

Methods: $\underline{\text { Clinical data of all term and preterm infants admitted to our tertiary neonatal }}$ intensive care unit from 1998 to 2007 with clinical signs of gastroenteritis (GE) or necrotizing enterocolitis (NEC) were retrospectively reviewed and compared between infants with different viral enteric pathogens in stool specimens.

Results: In thirty-four infants with signs of GE or NEC, enteropathogenic viruses were found in stool specimens. Rotavirus was detected in 12 cases, of which 2 infants had NEC. Compared with infants with rotavirus or norovirus, infants with astrovirus more frequently suffered from NEC $(p<0.05)$. In addition, an acute systemic inflammatory response was significantly more common in patients with astrovirus infection (astrovirus vs. rotavirus and astrovirus vs. norovirus $p<0.01$ and $p<0.05$, respectively). Of 8 children infected with norovirus, one infant had a systemic acute inflammatory response and NEC.

Conclusions: This study demonstrates that in newborn infants, intestinal rotavirus, norovirus, and astrovirus infections may be associated with severe illness such as hemorrhagic enteritis resulting in bloody diarrhea or even NEC. 


\section{INTRODUCTION}

Viral pathogens are the most frequent cause of endemic and outbreak-related GE and are responsible for significant morbidity and mortality in infants and children world-wide, both outbreak-related and endemic. Most episodes are due to infections with rotavirus (RV), human astrovirus (HAstV), norovirus (NV), and adenovirus (AdV) [1-2].

Etiologic studies of acute GE showed that RV is the major cause of clinically severe, epidemic and sporadic viral GE in young children, immunocompromized patients, and in the elderly [1]. NV and HAstV are usually associated with cases of mild and self-limiting GE in children [3-6].

In contrast to the usually self-limiting course of GE in healthy children, NEC, a major and life-threatening gastrointestinal emergency, has occasionally been reported associated with RV infection or colonization in preterm infants [7-9]. Moreover, we have previously shown that colonization or infection with HAstV may also be associated with severe confirmed NEC in preterm infants [10], and recently, Armbrust et al. [11] reported a NV outbreak in 11 premature infants in a tertiary Neonatal Intensive Care Unit (NICU), of whom 2 developed NEC.

With more sensitive virus identification techniques, viral GE has been increasingly reported in infants, especially in pediatric hospitals and child-care centers. The aim of this retrospective investigation was to evaluate the clinical presentation of viral intestinal infections especially with NV in newborns admitted to a NICU. 


\section{METHODS}

Medical records of 3402 newborn infants admitted between January 1998 and December 2007 to a tertiary NICU of the Department of Neonatology, University Hospital of Bonn were retrospectively reviewed for the diagnoses of GE or NEC. As several studies showed the relationship between pathogenic microorganisms and NEC [12], it has been routine care at our institution during this 10 year period to examine fecal specimens of all infants with one or more acute gastrointestinal symptoms such as abdominal distension, feeding difficulties, increased gastric residuals $(>5 \mathrm{ml} / \mathrm{kg}$ per feeding), vomiting, bloody stools, loose stools, or diarrhea by culture for enteric bacterial pathogens, by cell culture test (human foreskin fibroblasts) for Clostridium difficile cytotoxin, and by ELISA or PCR for a series of viral pathogens including RV, AdV, NV, and HAstV. When a new case with viral pathogen was identified, all patients who shared a room with the infected infant were immediately tested. All infants who were diagnosed to have NEC or GE were eligible for analysis. Infants without NEC or GE were excluded from the study if no viral or bacterial pathogens were detected in their stool specimens.

Case Definitions and Laboratory Methods: NEC was staged according to modified Bell's criteria [13], a definite case of NEC (stage $\geq I I A$ ) is an infant with one of the following intestinal or systemic signs: visible blood from rectum, apnoea, shock, hypotension or X-rays with positive signs of pneumatosis intestinalis; a suspected case of NEC (stage I) is a infant with at least two of the following clinical signs: abdominal distension, gastric residual (> $5 \mathrm{ml} / \mathrm{kg}$ per feeding), occult blood in stool or a radiological finding of persistent intestinal distension [14].

Although there was no clear definition to differentiate between NEC stage I and GE, we defined viral GE in this study by the presence of diarrhea defined as loose, watery 
stools that occur more than three times per day for at least three consecutive days and a positive ELISA or RT-PCR for a viral enteric pathogen but negative culture results for bacterial enteric pathogens and Clostridium difficile cytotoxin [14].

From all infant records, that contained the diagnoses GE or NEC with positive ELISA or RT-PCR for an enteric virus, the following data were extracted: Baseline characteristics; clinical features of the acute episode, standard laboratory tests, including complete blood cell count, basic metabolic profile, acute phase reactant including C-reactive protein and interleukin 6, reports of stool cultures, virus detection, therapeutic interventions, and complications. An acute systemic inflammatory response was defined as either C-reactive Protein $>10 \mathrm{mg} / \mathrm{l}$ [15] or Interleukin $6>100 \mathrm{pg} / \mathrm{ml}$ [16] and lactic acidosis was defined as lactate $>1.8 \mathrm{mmol} / \mathrm{l}$.

Examinations of viral pathogens were done by antigen-specific enzyme-linked immunabsorbent assay (ELISA) for RV (Premier Rotaclone, Meridian Bioscience, Inc. Cinncinati, USA), AdV (Premier Adenoclone, Meridian Bioscience, Inc. Cinncinati, USA) and HAstV (Amplified IDEIA Astrovirus, DakoCytomation, Carpinteria, CA, USA). All ELISAs were performed according to the manufacturer's instructions. NV was detected by RT-PCR as previously described [2, 17-19].

Statistical Analyses: Statistical analysis was performed by SPSS 17.0 software package for windows. Infants with evidence of different viral pathogens were compared using Fisher's Exact Test for dichotomous variables, Mann Whitney $U$ test for continuous variables which were not normally distributed and t-test for continuous variables with normal distribution. $\mathrm{P}<0.05$ was considered statistically significant. 


\section{RESULTS}

A total of 906 stool specimens from 567 infants were examined for gastrointestinal viruses and enteropathogenic bacteria. Of 220 infants, 108 (3.2\%) had NEC and 112 (3.3\%) had GE. In the other 347 infants, no viral or bacterial pathogens were detected and these infants were excluded from analysis.

Gastrointestinal viral agents were detected in 34 infants out of $220(15.5 \%)$ infants with GE and NEC; of these, 26 (77\%) were preterm infants at the onset of clinical signs. All patients with virus detection showed signs of GE $(n=22)$ or NEC $(n=12)$, of whom 6 had Bell's stage $\geq$ IIA NEC. There was no statistically significant difference in the gestational age between infants with and without viral enteric pathogens both in the GE group (median [range]: 34 [26-40] vs. 31 [23-40] weeks; $p=0.064$ ), and in the NEC group (29 [25-35] vs. 28 [23-41] weeks; $p=0.207)$, respectively.

$R V$ was detected in stool specimens of 12 infants, HAstV in 14, and NV in 8 infants. № adenovirus was identified. RV could be identified only during an outbreak of gastrointestinal rotavirus infections between January 1998 and June 1998. Moreover, $\underline{R V}$ was detected in the second stool specimen of an infant with HAstV who was admitted to the group of HAstV. The majority of cases with RV infection have been mild and self-limiting GE, but 2 preterm infants had signs of NEC.

Infants with detection of HAstV more frequently suffered from NEC $\geq$ IIA if compared with infants with detection of RV or $\mathrm{NV}(\mathrm{RV} n=2 / 12$. $\mathrm{NV} n=1 / 8, \mathrm{HAstV} n=9 / 14$; HAstV vs. RV and HAstV vs. NV $p<0.05$, respectively). In addition, analysis concerning the infants with GE (without NEC), HAstV GE showed more frequently an acute systemic inflammatory response (RV $n=0 / 10, N V n=1 / 7, H A s t V n=4 / 5$; HAstV vs. RV and HAstV vs. NV, $p<0.01$ and $p<0.05$, respectively). The clinical features of all neonates with clinical GE or NEC in whom viral pathogens were detected are summarized in Table 1. 
NV was detected in 8 newborns with a median gestational age of 29 weeks (range 2636 weeks). Of these 8 children, 5 (63\%) were still preterm at the onset of illness. Predominant clinical signs in infants in whom NV was detected were abdominal distension, diarrhea, and apnea. Four neonates $(n=4 / 8,50 \%)$ with detection of NV showed bloody stools and one of them displayed an acute inflammatory response with elevated values for C-reactive protein (maximum value $42.1 \mathrm{mg} / \mathrm{l})$, lactate $(4.5 \mathrm{mmol} / \mathrm{l})$ and clinical findings of NEC stage IB. In this infant oral feedings were withheld and antibiotics were administered for seven days. In one infant, repetitive stool specimens revealed a positive result for NV for 21 days after the onset of illness. The clinical features of infants in whom NV was detected are shown in Table 2. 


\section{DISCUSSION}

Although viral pathogens have been identified as cause of epidemics of hospitalacquired GE for many years, the association of viral agents with NEC in preterm infants has only recently been recognized [8-10,20-21]. Our study demonstrates that intestinal $\mathrm{RV}$, NV and HAstV infection in preterm and term neonates may be associated with severe illness such as hemorrhagic enteritis resulting in bloody diarrhea or even NEC and provides further evidence for the role of gastrointestinal viral infections in this most common gastrointestinal emergency in premature infants. Nevertheless, the etiologic role of gastrointestinal viral agents in the pathogenesis of hemorrhagic enteritis or NEC remains largely unknown $[1,22-23]$.

Rotavirus is the main viral pathogen that causes severe diarrheal diseases in infants and young children up to two years. In addition, several reports have described the association of NEC with RV infection or colonization [7-9]. In our cohort we found two patients with RV infection and NEC. Hypotheses of the mechanism of diarrhea include reduced absorptive surface, functionally impaired absorption, cellular damage impairing absorption, enterotoxic effects of rotavirus protein NSP4, and stimulation of the enteric nervous system [1, 22]. However, the role of RV in the pathogenesis of NEC has not been established. The authors suggested that a possible synergism between RV and other microorganism can worsen the infection in the intestine and cause necrotizing enterocolitis [1, 7-8]. Although all patients in our NICU received a regular screening for viral agents and enteric bacterial pathogens during an outbreak of RV infections, no other gastrointestinal pathogen microorganisms were detected. Furthermore, we found no asymptomatic RV carriers in our NICU at that time.

Although HAstV is usually associated with cases of mild and self-limiting GE in older children, we previously reported that colonization or infection with HAstV may be 
associated with the development of severe NEC in preterm infants [10]. Previously, Sirinavin et al. [24] described a HAstV outbreak in healthy neonates in a nursery of a maternity ward. However, so far neonatal cases are rare and outbreaks have not been reported from NICUs. Enteropathogenic viruses generally infect epithelial cells and result in cytolysis and cell destruction [25]. In symptomatic HAstV infection, viral particles have been detected in the low villous, and on the surface of the intestinal epithelium as well as in macrophages of the lamina propria. Investigations in an animal astrovirus model revealed vacuolization followed by degeneration and cell death leading to villous atrophy [26]. However, it is unclear which pathogenetic mechanisms are involved in the occurrence of acute systemic inflammatory response and intestinal ischaemia, i.e. in NEC, in infants with HAstV infection / colonization. Of our 14 infants infected with HAstV, $5(36 \%)$ had Bell's stage $\geq$ IIA NEC and $4(80 \%)$ of 5 infants with clinical GE showed an acute systemic inflammatory response. In contrast to older children, the intestinal epithelium in premature infants may not have the same regenerative capacity. Exaggerated inflammation caused by immature intestinal innate immunity may lead to the generation of toxic metabolites, enhance the epithelial damage and result in intestinal lesions recognized as necrosis. On the other hand, one could speculate that NEC or the systemic inflammatory response may result from bacterial translocation after mucosal damage as a result of a possible synergism between HAstV and bacteria or from the systemic spread of virus particles. However, we are unable to identify another bacterial enteropathogenic agent in stool and blood cultures in these infants.

Generally, NV infections are mild and self-limiting and diarrheal stool during NV infection is non-bloody, lacks mucus, and may be loose or watery $[4,6,27]$. In contrast, four of our 8 newborn infants with NV infection (50\%) had bloody stools and one of them 
had NEC [6]. Human noroviruses are thought to have an enteric tropism limited to the upper intestinal tract, because intestinal biopsies from volunteers revealed villous broadening and atrophy, crypt cell hyperplasia and cytoplasmic vacuolization in the jejunum and duodenum and an infiltration of polymorphonuclear and mononuclear cells into the lamina propria [28-31]. Similar pathology is seen in biopsies from pediatric transplant patients with diarrhea associated with human NV infection [32]. Histopathologic examination in the intestine of gnotobiotic pig's also showed mild lesions in the upper intestinal tract, but no cytopathic lesions [33]. Cheetham et al. [33] speculated that extensive histopathologic lesions may not be apparent in the intestine because the NV-infected enterocytes may be dying by apoptosis rather than necrosis. Recently, Turcios-Ruiz et al. [21] and Armbrust at al. [11] reported cases of NEC associated with NV in newborn infants similar to the case we describe in this report. Unfortunately none of these studies provided information on the histopathologic examination of colons to establish the involvement of the colon with NV infection / colonization in premature newborn infants.

In summary, just like other authors [34-36], we can only speculate that viral infections in preterm infants may increase epithelial cell damage leading to weakening of the mucosal barrier and occasionally resulting in NEC. The limitations of our study are the retrospective design, the lack of data on the prevalence of gastrointestinal viruses in stool specimen of infants without gastrointestinal symptoms and the lack of data concerning the time course of the development of GE or NEC with regard to the onset of colonization / infection with viruses. In order to understand the prevalence of enteric viruses in neonatal intensive care units and their role in the pathophysiology of NEC, gastrointestinal viruses should be included in the microbiological examination of stool specimens in patients with gastrointestinal symptoms and further studies are necessary. 


\section{REFERENCES}

[1] Clark B, McKendrick M (2004) A review of viral gastroenteritis. Curr Opin Infect Dis $17(5): 461-469$

[2] Oh DY, Gaedicke G, Schreier E (2003) Viral agents of acute gastroenteritis in German children: prevalence and molecular diversity. J Med Virol 71 (1):82-93

[3] Walter JE, Mitchell DK (2003) Astrovirus infection in children. Curr Opin Infect Dis $16(3): 247-253$

[4] Patel MM, Widdowson MA, Glass RI, Akazawa K, Vinje J, Parashar UD (2008) Systematic literature review of role of noroviruses in sporadic gastroenteritis. Emerg Infect Dis 14 (8):1224-1231

[5] Simon A, Schildgen O, Maria Eis-Hubinger A, Hasan C, Bode U, Buderus S, Engelhart S, Fleischhack G (2006) Norovirus outbreak in a pediatric oncology unit. Scand J Gastroenterol 41 (6):693-699

[6] Thornton AC, Jennings-Conklin KS, McCormick MI (2004) Noroviruses: agents in outbreaks of acute gastroenteritis. Disaster Manag Response 2 (1):4-9

[7] Rotbart HA, Levin MJ, Yolken RH, Manchester DK, Jantzen J (1983) An outbreak of rotavirus-associated neonatal necrotizing enterocolitis. J Pediatr 103 (3):454-459 [8] Sharma R, Garrison RD, Tepas JJ, 3rd, Mollitt DL, Pieper P, Hudak ML, Bradshaw JA, Stevens G, Premachandra BR (2004) Rotavirus-associated necrotizing enterocolitis: an insight into a potentially preventable disease? J Pediatr Surg 39 (3):453-457

[9] Herruzo R, Omenaca F, Garcia S, Diez J, Sanchez-Fauquier A (2009) Identification of risk factors associated with nosocomial infection by rotavirus P4G2, in a neonatal unit of a tertiary-care hospital. Clin Microbiol Infect 15 (3):280-285 
[10] Bagci S, Eis-Hubinger AM, Franz AR, Bierbaum G, Heep A, Schildgen O,

Bartmann P, Kupfer B, Mueller A (2008) Detection of astrovirus in premature infants with necrotizing enterocolitis. Pediatr Infect Dis J 27 (4):347-350

[11] Armbrust S, Kramer A, Olbertz D, Zimmermann K, Fusch C (2009) Norovirus infections in preterm infants: wide variety of clinical courses. BMC Res Notes 2:96 [12] Caplan MS, Jilling T (2001) New concepts in necrotizing enterocolitis. Curr Opin Pediatr 13 (2):111-115

[13] Bell MJ, Ternberg JL, Feigin RD, Keating JP, Marshall R, Barton L, Brotherton T (1978) Neonatal necrotizing enterocolitis. Therapeutic decisions based upon clinical staging. Ann Surg 187 (1):1-7

[14] Faustini A, Forastiere F, Giorgi Rossi P, Perucci CA (2004) An epidemic of gastroenteritis and mild necrotizing enterocolitis in two neonatal units of a University Hospital in Rome, Italy. Epidemiol Infect 132 (3):455-465

[15] Weitkamp J-H, Aschner JL (2005) Diagnostic use of C-reactive protein (CRP) in assessment of neonatal sepsis. NeoReviews 6 (11):e508-e515

[16] Krueger M, Nauck MS, Sang S, Hentschel R, Wieland H, Berner R (2001) Cord blood levels of interleukin- 6 and interleukin-8 for the immediate diagnosis of early-onset infection in premature infants. Biol Neonate 80 (2):118-123

[17] Ando T, Monroe SS, Noel JS, Glass RI (1997) A one-tube method of reverse transcription-PCR to efficiently amplify a 3-kilobase region from the RNA polymerase gene to the poly(A) tail of small round-structured viruses (Norwalk-like viruses). J Clin Microbiol 35 (3):570-577

[18] Hohne M, Schreier E (2004) Detection and characterization of norovirus outbreaks in Germany: application of a one-tube RT-PCR using a fluorogenic real-time detection system. J Med Virol 72 (2):312-319 
[19] Schreier E, Doring F, Kunkel U (2000) Molecular epidemiology of outbreaks of gastroenteritis associated with small round structured viruses in Germany in 1997/98. Arch Virol 145 (3):443-453

[20] Lodha A, de Silva N, Petric M, Moore AM (2005) Human torovirus: a new virus associated with neonatal necrotizing enterocolitis. Acta Paediatr 94 (8):1085-1088 [21] Turcios-Ruiz RM, Axelrod P, St John K, Bullitt E, Donahue J, Robinson N, Friss HE (2008) Outbreak of necrotizing enterocolitis caused by norovirus in a neonatal intensive care unit. J Pediatr 153 (3):339-344

[22] Lundgren O, Svensson L (2001) Pathogenesis of rotavirus diarrhea. Microbes Infect $3(13): 1145-1156$

[23] Mumphrey SM, Changotra H, Moore TN, Heimann-Nichols ER, Wobus CE, Reilly MJ, Moghadamfalahi M, Shukla D, Karst SM (2007) Murine norovirus 1 infection is associated with histopathological changes in immunocompetent hosts, but clinical disease is prevented by STAT1-dependent interferon responses. J Virol 81 (7):32513263

[24] Sirinavin S, Techasaensiri C, Okascharoen C, Nuntnarumit P, Tonsuttakul S, Pongsuwan $Y$ (2006) Neonatal astrovirus gastroenteritis during an inborn nursery outbreak. J Hosp Infect 64 (2):196-197

[25] Lundgren O, Peregrin AT, Persson K, Kordasti S, Uhnoo I, Svensson L (2000) Role of the enteric nervous system in the fluid and electrolyte secretion of rotavirus diarrhea. Science 287 (5452):491-495

[26] Mitchell DK (2002) Astrovirus gastroenteritis. Pediatr Infect Dis J 21 (11):10671069 
[27] Graham DY, Jiang X, Tanaka T, Opekun AR, Madore HP, Estes MK (1994)

Norwalk virus infection of volunteers: new insights based on improved assays. J Infect Dis $170(1): 34-43$

[28] Dolin R, Blacklow NR, DuPont H, Buscho RF, Wyatt RG, Kasel JA, Hornick R, Chanock RM (1972) Biological properties of Norwalk agent of acute infectious nonbacterial gastroenteritis. Proc Soc Exp Biol Med 140 (2):578-583

[29] Guo M, Hayes J, Cho KO, Parwani AV, Lucas LM, Saif LJ (2001) Comparative pathogenesis of tissue culture-adapted and wild-type Cowden porcine enteric calicivirus (PEC) in gnotobiotic pigs and induction of diarrhea by intravenous inoculation of wildtype PEC. J Virol 75 (19):9239-9251

[30] Schreiber DS, Blacklow NR, Trier JS (1973) The mucosal lesion of the proximal small intestine in acute infectious nonbacterial gastroenteritis. N Engl J Med 288 $(25): 1318-1323$

[31] Wobus CE, Thackray LB, Virgin HWt (2006) Murine norovirus: a model system to study norovirus biology and pathogenesis. J Virol 80 (11):5104-5112

[32] Morotti RA, Kaufman SS, Fishbein TM, Chatterjee NK, Fuschino ME, Morse DL, Magid MS (2004) Calicivirus infection in pediatric small intestine transplant recipients: pathological considerations. Hum Pathol 35 (10):1236-1240

[33] Cheetham S, Souza M, Meulia T, Grimes S, Han MG, Saif LJ (2006) Pathogenesis of a genogroup II human norovirus in gnotobiotic pigs. J Virol 80 (21):10372-10381

[34] Kliegman RM, Walker WA, Yolken RH (1993) Necrotizing enterocolitis: research agenda for a disease of unknown etiology and pathogenesis. Pediatr Res 34 (6):701 708

[35] Lin PW, Stoll BJ (2006) Necrotising enterocolitis. Lancet 368 (9543):1271-1283 
[36] Markel TA, Crisostomo PR, Wairiuko GM, Pitcher J, Tsai BM, Meldrum DR (2006) Cytokines in necrotizing enterocolitis. Shock 25 (4):329-337 
Table1. Neonatal Characteristics and Clinical Findings of Newborns with Enteric Viral Infection

\begin{tabular}{|c|c|c|c|c|c|}
\hline Characteristics & $\begin{array}{l}\text { Total } \\
(n=34)\end{array}$ & $\begin{array}{l}\text { Rotavirus } \\
\qquad(\mathrm{n}=12)\end{array}$ & $\begin{array}{l}\text { Astrovirus } \\
\text { (n=14) }\end{array}$ & $\begin{array}{l}\text { Norovirus } \\
\qquad(\mathrm{n}=8)\end{array}$ & $P$ Value* \\
\hline Birth weight $(g)^{\#}$ & $\begin{array}{c}1620 \\
(618-3790)\end{array}$ & $\begin{array}{c}1700 \\
(940-3080)\end{array}$ & $\begin{array}{c}1690 \\
(618-3340)\end{array}$ & $\begin{array}{c}1335 \\
(670-3790)\end{array}$ & n.s. \\
\hline Gestational age (weeks) ${ }^{\#}$ & $32(25-40)$ & $33(27-40)$ & $33(25-40)$ & $29(26-36)$ & n.s. \\
\hline Male gender (\%) & $20(59)$ & $7(58)$ & $11(79)$ & $2(25)$ & $p<0.05 \ddagger$ \\
\hline Surfactant treatment (\%) & $8(24)$ & $3(25)$ & $2(14)$ & $3(38)$ & n.s. \\
\hline Postnatal age at onset of illness $(d)^{\#}$ & $15(2-92)$ & $26(6-45)$ & $13(2-45)$ & $25(8-92)$ & $p<0.05 \S \ddagger$ \\
\hline Gastroenteritis (\%) & $22(65)$ & $10(83)$ & $5(36)$ & $7(88)$ & $p<0.05 \S \ddagger$ \\
\hline NEC (\%) & $12(35)$ & $2(17)$ & $9(64)$ & $1(12)$ & $p<0.05 \S \ddagger$ \\
\hline NEC Bell's stage $\geq I I A(\%)$ & $6(18)$ & $1(8)$ & $5(36)$ & - & n.s. \\
\hline Surgery (\%) & $5(15)$ & $1(8)$ & $4(29)$ & - & n.s. \\
\hline Duration of illness $(d)^{\#}$ & $3(2-21)$ & $3(2-21)$ & $2(2-3)$ & $5(2-11)$ & $p<0.05 \ddagger$ \\
\hline Mortality (\%) & - & - & - & - & \\
\hline $\begin{array}{l}\text { Symptoms of newborns with } \\
\text { gastroenteritis }\end{array}$ & 22 & 10 & 5 & 7 & \\
\hline $\begin{array}{l}\text { Diarrhea (\% of those with } \\
\text { gastroenteritis) }\end{array}$ & $22(100)$ & $10(100)$ & $5(100)$ & $7(100)$ & n.s. \\
\hline $\begin{array}{l}\text { Gastric residue ((\% of those with } \\
\text { gastroenteritis)) }\end{array}$ & 7 ( 32) & $2(20)$ & $3(60)$ & $2(29)$ & n.s. \\
\hline $\begin{array}{l}\text { Vomiting (\% of those with } \\
\text { gastroenteritis) }\end{array}$ & $9(41)$ & $5(50)$ & $1(20)$ & $3(43)$ & n.s. \\
\hline $\begin{array}{l}\text { Abdominal distension (\% of those } \\
\text { with gastroenteritis) }\end{array}$ & $11(50)$ & $3(30)$ & $2(40)$ & $7(100)$ & $\begin{array}{l}p<0.05 \ddagger \\
p<0.01 \dagger\end{array}$ \\
\hline $\begin{array}{l}\text { Blood in stool (\% of those with } \\
\text { gastroenteritis) }\end{array}$ & $4(18)$ & $1(10)$ & - & $3(43)$ & n.s. \\
\hline $\begin{array}{l}\text { Apnea (\% of those with } \\
\text { gastroenteritis) }\end{array}$ & $9(41)$ & $3(30)$ & $3(60)$ & $4(57)$ & n.s. \\
\hline $\begin{array}{l}\text { Acute systemic inflammatory } \\
\text { response ( } \% \text { of those with } \\
\text { gastroenteritis) }\end{array}$ & $5(23)$ & - & $4(80)$ & $1(14)$ & $\begin{array}{l}p<0.05 \ddagger \\
p<0.01 \S\end{array}$ \\
\hline
\end{tabular}

"Data are expressed as median (range), ${ }^{\#} \mathrm{n}=$ Gastroenteritis

n.s. not significant ( $p>0,05)$ (Rotavirus vs. Astrovirus, Rotavirus vs. Norovirus, Astrovirus vs. Norovirus)

$\S$ Rotavirus vs. Astrovirus; † Rotavirus vs. Norovirus; $\ddagger$ Astrovirus vs. Norovirus 
Table 2. Neonatal Characteristics and Clinical Findings in Patients with Gastroenteritis or NEC and Detection of Norovirus

\begin{tabular}{|c|c|c|c|c|c|c|c|c|}
\hline Characteristics & Case 1 & Case 2 & Case 3 & Case 4 & Case 5 & Case 6 & Case 7 & Case 8 \\
\hline Birth weight (g) & 1830 & 885 & 670 & 2800 & 1620 & 1050 & 3790 & 910 \\
\hline Gestational age (weeks) & $33+3$ & $26+5$ & $27+1$ & $34+0$ & $29+5$ & $28+4$ & $36+1$ & $26+1$ \\
\hline Gender & $\mathrm{F}$ & $\mathrm{F}$ & $\mathrm{F}$ & $\mathrm{F}$ & $\mathrm{F}$ & $\mathrm{F}$ & M & M \\
\hline Age at onset of illness $(d)(W)$ & $11(34+6)$ & $92(39+5)$ & $59(35+4)$ & $36(39+1)$ & $17(32+1)$ & $23(31+6)$ & $28(40+1)$ & $7(27+1)$ \\
\hline Month/ year at onset of illness & March 04 & August 04 & August 04 & August 04 & August 04 & September 04 & January 05 & October 07 \\
\hline $\begin{array}{l}\text { Increased gastric residue (>5 } \\
\mathrm{ml} / \mathrm{kg} \text { ) }\end{array}$ & - & - & - & - & + & - & + & - \\
\hline Vomiting & + & - & - & + & - & - & + & - \\
\hline Abdominal distension & + & + & + & + & + & + & + & + \\
\hline Diarrhea & + & + & + & + & + & + & + & - \\
\hline Duration of occult blood in stool & 3 & 11 & - & - & - & - & 8 & 1 \\
\hline Apnoea & - & + & + & - & + & + & - & + \\
\hline $\begin{array}{l}\text { Acute systemic inflammatory } \\
\text { response* }\end{array}$ & - & - & - & - & - & - & - & + \\
\hline Lactic acidosis ${ }^{\#}$ & - & - & + & - & - & - & - & + \\
\hline Diagnosis & gastroenteritis & gastroenteritis & gastroenteritis & gastroenteritis & gastroenteritis & gastroenteritis & gastroenteritis & NEC \\
\hline
\end{tabular}

${ }^{*}$ CRP $>10 \mathrm{mg} / \mathrm{l}$ and/or IL-6 $>100 \mathrm{pg} / \mathrm{ml},{ }^{*}$ Lactate $>1.8 \mathrm{mmol} / \mathrm{l}$, NEC: Necrotizing enterocolitis 